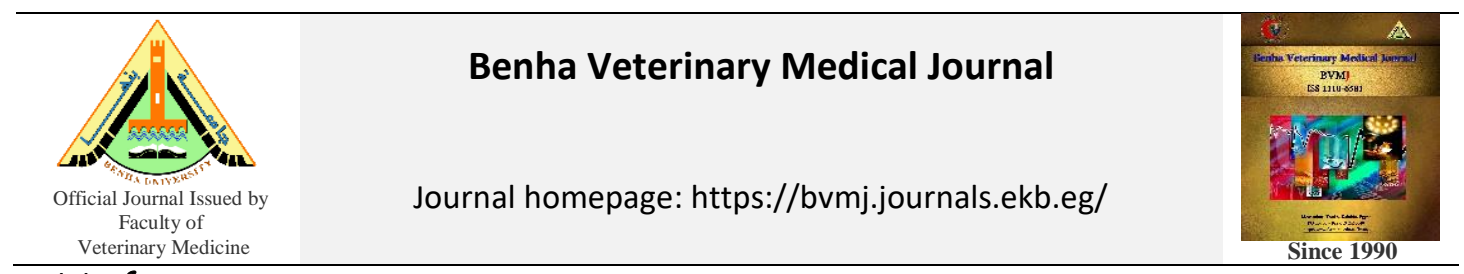

Original Paper

\title{
Prevalence and molecular characterization of Lumpy Skin Disease in cattle during period 2016-2017
}

\author{
Mona Dawoud $^{1}$, Abdel-Fataah Selim ${ }^{1}$, Abdelmoneim Moustafa ${ }^{1}$, Sayed Salem $^{2}$ \\ ${ }^{I}$ Department of animal Medicine, Faculty of Veterinary Medicine Benha University \\ ${ }^{2}$ Animal Health Research Institute (AHRI) Dokki, Giza, Egypt
}

\begin{tabular}{|c|c|}
\hline ARTICLE INFO & ABSTRACT \\
\hline $\begin{array}{l}\text { Keywords } \\
\text { ELISA } \\
\text { LSD } \\
\text { PCR } \\
\text { Sequencing } \\
\text { Phylogenetic analysis } \\
\text { Received 16/10/2019 } \\
\text { Accepted 18/11/2019 } \\
\text { Available On-Line } \\
\text { 12/05/2020 }\end{array}$ & $\begin{array}{l}\text { The present study was carried out to determine the prevalence of Lumpy skin disease (LSD) in } \\
\text { different governorates in Egypt in relation to different factors. A total of } 875 \text { blood samples } \\
\text { and } 10 \text { specimens (skin nodules) were collected from apparently health and clinically infected } \\
\text { balady cattle of different ages and two sexes in different seasons during period } 2016-2017 \text {. } \\
\text { The prevalence of LSD in cattle in different governorates was } 35.4 \%, 29.6 \%, 25.3 \%, 24.7 \% \text {, } \\
15.6 \% \text { and } 13.8 \% \text { in Beni Suef, El-Faiyum, EL-Dakahlia, El-Qalyubia, El-Beheira and El- } \\
\text { Gharbia, respectively. The prevalence of the disease was higher in females (29.2\%) than males } \\
(21.2 \%) \text {. Also, the prevalence rate was higher in age group (>12-36 m) } 33 \% \text { and (> 36-50 m) } \\
23.5 \% \text { in comparison with age groups ( } 3-6 \mathrm{~m}) 15.6 \% \text { and (> } 6-12 \mathrm{~m}) 16 \% \text {. The disease was } \\
\text { highly occurred during summer and autumn ( } 27.6 \% \text { and } 26 \% \text {, respectively). PCR reaction was } \\
\text { carried out on skin nodules samples to confirm and characterize LSDV. selective positive } \\
\text { samples undergo sequencing and compared with other LSDV strains and also other Capri- } \\
\text { poxviruses in database in GenBank. The local LSDV samples reveled high identity in } \\
\text { phylogenetic analysis to each other and high identity and clustered with other world LSDV } \\
\text { strains and Capri-poxvirust. }\end{array}$ \\
\hline
\end{tabular}

\section{INTRODUCTION}

Lumpy skin disease (LSD) is a highly infectious disease of cattle caused by Neethling pox virus of genus Capripoxvirus belongs to family poxviridae (Al-Salihi, 2014). LSD was first reported in Central and southern Africa then continues to circulate through the Middle East region and spread also in non-African countries in Asia and Europe (Abutarbush et al., 2015; Tageldin et al., 2014). The first LSD case had been recorded In Egypt in 1988 (House et al1990). At least two outbreaks occurred between 1989 and 2006 (El-Kholy et al., 2008; and Salib and Osman, 2011). Specific vector of LSDV was not absolutely confirmed, but there are strong evidences supporting that the LSDV was mechanically transmitted by Aedes mosquitoes (Chihota et al., 2001) and by ticks (Tuppurainen et al., 2011). LSD affecting cattle of all ages and breeds but the young calves and cows in the peak of lactation are more severely affected (Tageldin et al., 2014). The disease is characterized by sudden eruption of nodules on the skin, which may cover the whole body of the animal accompanied by fiver\& systemic effects including pyrexia, anorexia, pneumonia, and generalized lymphadenopathy (Abutarbush et al., 2015). The disease cause considerable economic losses due to fertility problems, reduced milk production and damage to the hide in addition to high morbidity rate with some mortalities (Molla et al., 2017). The diagnosis usually based on serological analysis like ELISA (Alkhamis and VanderWaal, 2016) or molecular technique like PCR assay, which is specific, rapid, sensitive and accurate assay for detection of LSDV (Pestova et al., 2018).

The study aimed to determine the prevalence of LSD in some governorates in Egypt. In addition, molecular detection and characterization of Egyptian LSD strain.

\section{MATERIAL AND METHODS}

\subsection{Sampling}

2.1.1. Serum samples

A total of 875 serum samples were collected from clinically infected (300) and apparent healthy cattle (575) during the period from February 2016 to December 2017 from different governorates (El-Faiyum- El-Beheira- El-Qalyubia- ElGharbia- EL-Dakahlia - Beni Suef).

\subsubsection{Tissue specimens}

Ten specimens (skin nodules) including whole skin thickness and skin crusts were collected for detection and typing of local virus strain.

\subsection{Serological analysis}

All collected serum samples were examined using ID Screen Capri-pox Double Antigen Multi-species (CPVDA-5P, ID vet innovative Diagnostics, France). The serological test

\footnotetext{
* Corresponding author: Prof. Abdelmoneim Moustafa- Department of animal Medicine, Faculty of Veterinary

Medicine Benha University
} 
(indirect ELISA) was carried according to manufacturer's instruction.

\subsection{Molecular typing}

The viral DNA was examined with specific pairs of primer LSDVF (5'actagtggatccATGGACAGAGCTTTATCA 3) and LSDVR (5'gctgcaggaattcTCATAGTGTTGTACTTCG 3) to amplify $472 \mathrm{bp}$ fragment. PCR product was analyzed on $1.5 \%$ agarose gel electrophoresis.

The product of two positive samples was partially sequenced targeting fusion gene. The purified PCR products were sequenced directly using the ABI PRISM ${ }^{\circledR}$ Big Dye TM Terminators v 3.1 Cycle Sequencing Kit (Applied Biosystems, Foster City, CA, USA). The sequences were edited and alignment was done with BioEdit software. Also, the phylogenetic analysis for the obtained sequence were performed by Mega7 software using the neighbor-joining tree method with 1000 bootstrap replicates.

\section{RESULTS}

The results of clinical investigation of animals under study revealed that the clinical signs began with fever, anorexia, skin lesions in the form of nodules all over the body. It was complicated with respiratory manifestation and corneal opacity. Necrosis and ulceration occurred and slough off leaving large ulcerative wound.

The prevalence rate of LSD varied between different localities under study. It was $35.4 \%, 29.6 \%, 25.3 \%, 24.7 \%$, $15.6 \%$ and $13.8 \%$ in Beni Suef, El-Faiyum, EL-Dakahlia, El-Qalyubia, El-Beheira and El-Gharbia, respectively, as shown in table 1.

The prevalence was higher in female $29.2 \%$ than in male $21.2 \%$ as in table 3 . The prevalence was higher $(33 \%$ and $23.5 \%)$ in age groups $(>12-36 \mathrm{~m})$ and $(>36-50 \mathrm{~m})$ in comparison with other age groups as shown in table 2 . The prevalence of the disease was higher during summer $27.6 \%$ and autumn $26 \%$, table 3 .

\begin{tabular}{lccc}
\multicolumn{3}{l}{ Table 1 The prevalence of LSD in examined cattle in relation to areas } \\
\hline Govern & $\begin{array}{c}\text { Total examined } \\
\text { cattle }\end{array}$ & $\begin{array}{c}\text { No. of infected } \\
\text { animals }\end{array}$ & $\begin{array}{c}\text { Percentage of } \\
\text { infection }\end{array}$ \\
\hline Beni Suef & 164 & 58 & $35.4 \%$ \\
El-Faiyum & 152 & 45 & $29.6 \%$ \\
EL-Dakahlia & 150 & 38 & $25.3 \%$ \\
El-Qalyubia & 97 & 24 & $24.7 \%$ \\
El-Gharbia & 203 & 28 & $15.6 \%$ \\
El-Beheira & 109 & 17 & $13.8 \%$ \\
total & 875 & 210 & $24.0 \%$ \\
\hline
\end{tabular}

Table 2 The prevalence of LSD in examined cattle in relation to sex

\begin{tabular}{lccc}
\hline Sex & Total examined cattle & Infected & Percentage of infection \\
\hline Female & 308 & 90 & $29.2 \%$ \\
Male & 567 & 120 & $21.2 \%$ \\
\hline
\end{tabular}

$P$ value 0.039

Table 3 The prevalence of LSD in examined cattle in relation to age

\begin{tabular}{lccc}
\hline Age & Total examined cattle & Infected & Percentage of infection \\
\hline 3-6 months & 96 & 15 & $15.6 \%$ \\
$>$ >- 12 months & 374 & 60 & $16.0 \%$ \\
$>12-36$ months & 269 & 89 & $33.0 \%$ \\
$>36-50$ months & 136 & 32 & $23.5 \%$ \\
\hline
\end{tabular}

The results revealed that ten skin samples were positive by PCR assay with amplified a DNA fragment of $472 \mathrm{bp}$ as shown in fig 1 . Two selective samples undergo sequencing and compared with other LSDV and other Capri-poxviruses in GenBank. The local LSDV samples reveled high identity to each other and high identity and clustered with other world LSDV strains and Capri-poxviruses. The isolated strains genetically characterized as lumpy skin disease virus by partial sequence of fusion gen (LSDV117) with high similarity to Herbivac LS strain, Neethling vaccine LW1959 strain, Sheep pox virus isolate Srinagar 38/00 fusion protein gen and Lumpy skin disease virus isolate Evros/GR/15 strain by Phylogenetic analysis figure (3) and (4).

\begin{tabular}{|c|c|c|c|}
\hline Season & Total examined cattle & Infected & Percentage of infection \\
\hline Summer & 398 & 110 & $27.6 \%$ \\
\hline spring & 122 & 25 & $20.5 \%$ \\
\hline Autumn & 153 & 40 & $26 \%$ \\
\hline Winter & 202 & 35 & $17.3 \%$ \\
\hline
\end{tabular}

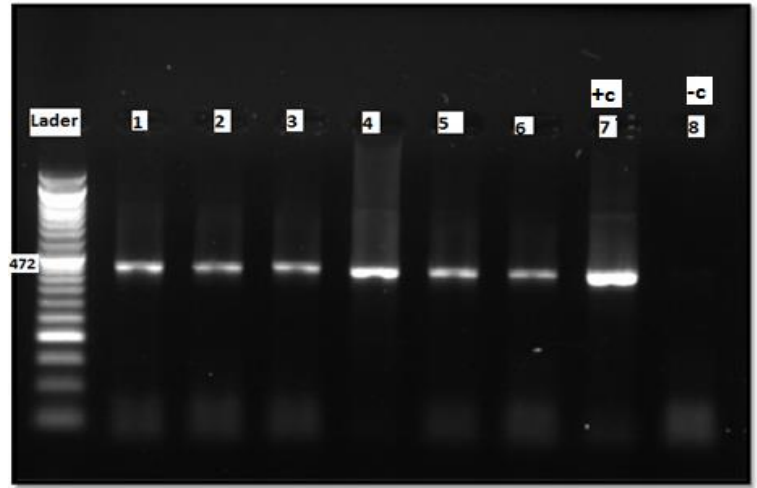

Figure 1the PCR amplicons (472 bp) of genomic DNA from lane 1 till lane 6 the tasted samples (all tested samples are $+v$ ) give specific band at $472 \mathrm{pb}$. Lane 7 and 8 are $+v$ control $\&$-v control.

\section{DISCUSSION}

LSD is considered as enzootic disease in Egypt and causes severe cyclical outbreaks continue to occur in Egypt (Salib and Osman, 2011). Control of the disease to decrease the economic losses is depending on rapid and accurate diagnosis (Aspden et al., 2002). In the present study, clinical findings in suspected lumpy skin diseased cows were reported in Governorates under consideration began with fever, anorexia, skin lesions in a form of nodules all over the body. It was complicated with respiratory manifestation, corneal opacity. Necrosis and ulceration were occurred and slough off leaving large ulcerative wound. This agreement with signs recorded by (Tuppurinen and Oura 2012; Abutarbush et al., 2015). The results showed that the prevalence of the disease in cattle was higher in Beni Suef and El-Faiyum in comparison with other studied areas. This may be due to high insect populations and defects in vaccination programs in these governorates. Regarding to sex, the prevalence of the disease in females is more than males by significance difference which come in agreement with Ayelet et al. (2014) and Elhaig et al. (2017). 


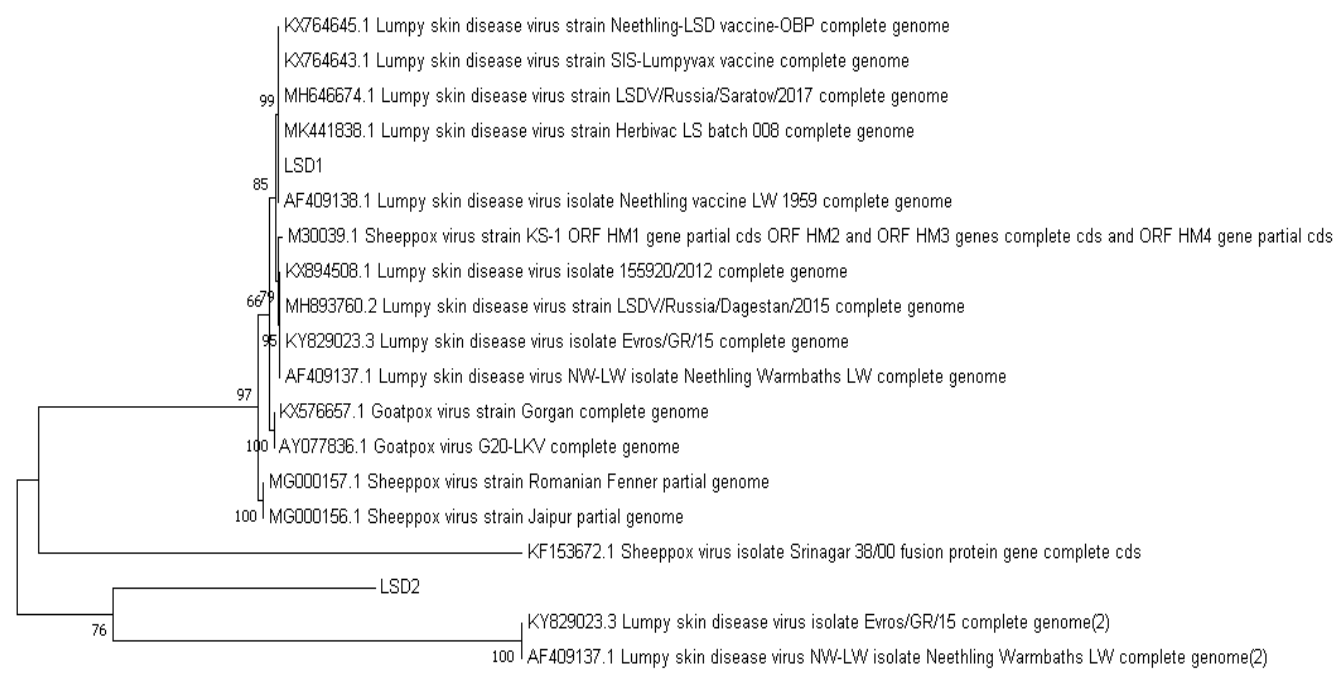

$\vdash 010$

Figure 2 Phylogenetic analysis of fusion gene of LSDV

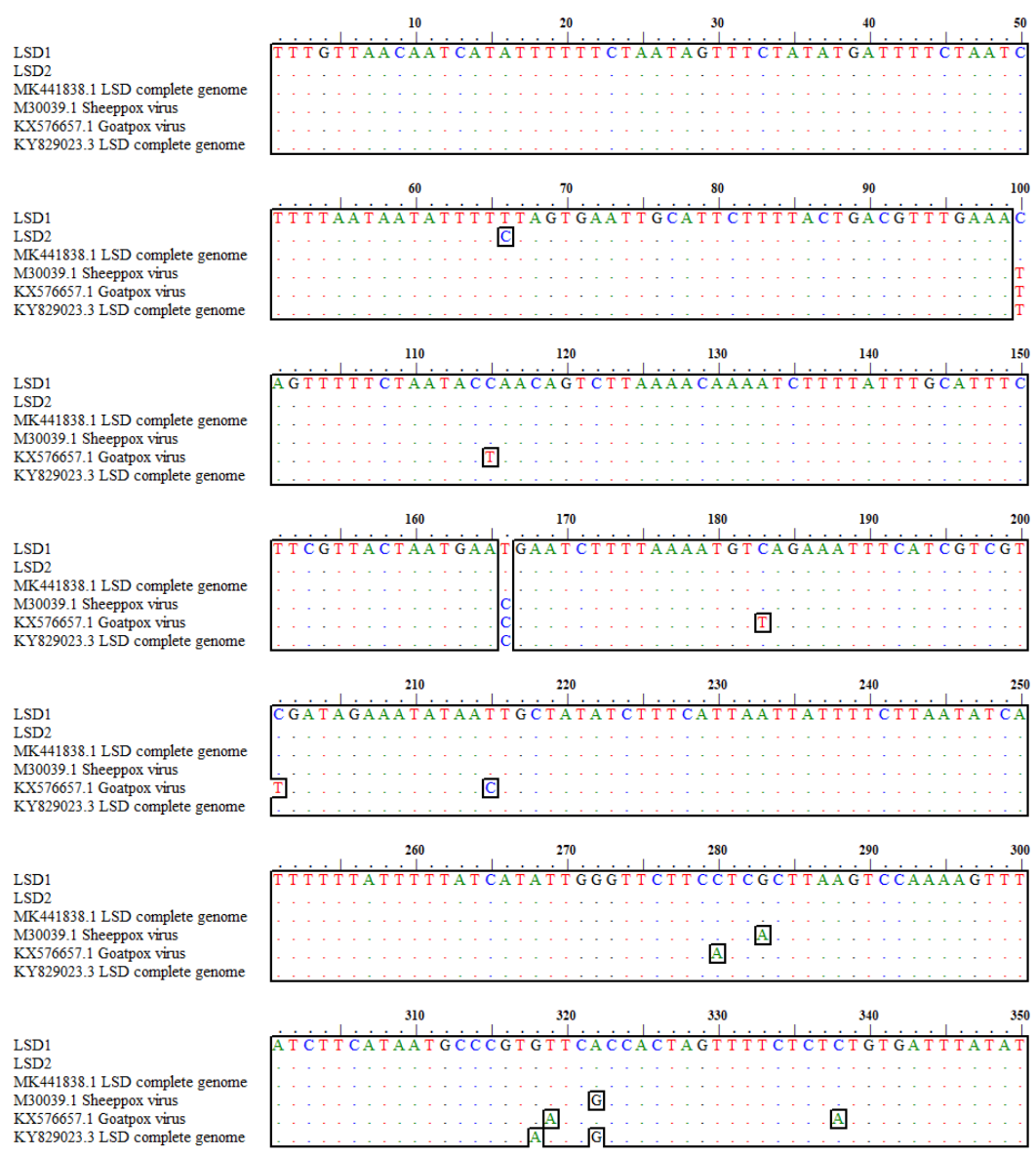

Figure 3 Alignment report of partially Nucleotide sequence of fusion gene of LSDV

This result may be due to stress factors as pregnancy, lactation and overcrowding (Tuppurainen et al., 2011). The obtained results revealed that the disease more occurred in older animals than young ones, this evidence come in agreement with that recorded by Sameea Yousefi et al. (2017). This may be due stress factors as pregnancy, lactation and fattening. However, other studies proved that the cattle of young ages were more susceptible than the oldest (Ayelet et al., 2014; Tuppurainen et al., 2011). In this study, the low prevalence of the disease in young ages may be due to passive maternal immunity (Adedeji et al., 2017). 
Also, the results showed that LSD was more common during summer and autumn. This may be due to warm, wet weather that motivated the growth and distribution of insects which considered the main vector in transmission of LSDV (Chihota et al., 2001; Gari et al., 2015). The results come in accordance with previous studies (Al-Salihi and Hassan, 2015; Şevik et al., 2016). The phylogenetic analyses and sequence alignments of local LSDV isolates showed that the LSD viral isolates were highly identical to each other and closed related to other LSDV strains and other Capripoxviruses (goat and sheep pox) strains. These results agreed with the theory which proved that all capri-poxviruses are genetically related and originated from the same lineage (Tulman et al., 2001). So cattle have been vaccinated with SPV will develop neutralizing antibodies to LSDV (Chihota et al., 2001). These results support the justified use of sheep pox virus vaccine for control of LSD and agree with the previous work of many authors (El-Kholy et al., 2008; ElTholoth and El-Kenawy, 2016).

\section{CONCULSION}

From the previous results, it can be concluded that, the LSD is endemic disease in Egypt and causes severe economic losses in cattle industry. The obtained results explain that the LSD is widespread in different governorate in Egypt in all age and both sexes of the cattle all over the year by different percentage. Direct sequencing of PCR amplicons and comparative genetic analyses were useful for epidemiological studies and development of new efficient LSDV vaccines

\section{REFERENCES}

1. Abutarbush, S., Ababneh, M., Al Zoubi, I., Al Sheyab, O., Al Zoubi, M., Alekish, M., Al Gharabat, R., 2015. Lumpy Skin Disease in J ordan: Disease Emergence, Clinical Signs, Complications and Preliminary-associated Economic Losses. Transbound. Emerg. Dis., 62: 549-554.

2. Adedeji, A., Adole, J., Dogonyaro, B., Kujul, N., Tekki, I., Asala, O., Chima, N., Dyek, Y., Maguda, A., Aba-Adulugba, E., 2017. Recurrent outbreaks of lumpy skin disease and its economic impact on a dairy farm in Jos, Plateau State, Nigeria. N.V.J., 38: 151-158.

3. Al-Salihi, K., 2014. Lumpy skin disease: Review of literature. M.R.V.S.A., 3: 6-23.

4. Al-Salihi, K., Hassan, I., 2015. Lumpy skin disease in Iraq: study of the disease emergence. Transbound. Emerg. Dis. 62: 457-462.

5. Alkhamis, M.A., VanderWaal, K., 2016. Spatial and temporal epidemiology of lumpy skin disease in the Middle East, 20122015. Front. Vet. Sci., 3:3-19.

6. Aspden, K., van Dijk, A.A., Bingham, J., Cox, D., Passmore, J.-A., Williamson, A.-L., 2002. Immunogenicity of a recombinant lumpy skin disease virus (neethling vaccine strain) expressing the rabies virus glycoprotein in cattle. Vaccine 20, 2693-2701.

7. Ayelet, G., Haftu, R., Jemberie, S., Belay, A., Gelaye, E., Sibhat, B., Skjerve, E., Asmare, K., 2014. Lumpy skin disease in cattle in central Ethiopia: outbreak investigation and isolation and molecular detection of the virus. Rev. Sci. Tech $33,877-887$.

8. Chihota, C., Rennie, L., Kitching, R., Mellor, P., 2001 Mechanical transmission of lumpy skin disease virus by Aedes aegypti (Diptera: Culicidae). Epidemiology \& Infection 126, 317-321.

9. El-Kholy, A.A., Soliman, H.M., Abdelrahman, K.A., 2008. Polymerase chain reaction for rapid diagnosis of a recent lumpy skin disease virus incursion to Egypt. Arab J Biotechnol 11, 293-302.

10. El-Tholoth, M., El-Kenawy, A., 2016. G-Protein-Coupled Chemokine Receptor Gene in Lumpy Skin Disease Virus Isolates from Cattle and Water Buffalo (B ubalus bubalis) in E gypt. Transboundary and emerging diseases 63, e288-e295.

11. Elhaig, M.M., Selim, A., Mahmoud, M., 2017. Lumpy skin disease in cattle: Frequency of occurrence in a dairy farm and a preliminary assessment of its possible impact on Egyptian buffaloes. Onderstepoort Journal of Veterinary Research 84, 1-6.

12. House, J.A., Wilson, T.M., EL-Nakashly, S., Karim, I.A., Ismail, I., EL-Danaf, N., Moussa, A.N. , Ayoub, N.N. 1990:"The isolation of lumpy skin disease virus and bovine herpes virus from cattle in Egypt" J. Vet. Diag. Invest., 2 (5): 111 115

13. Gari, G., Abie, G., Gizaw, D., Wubete, A., Kidane, M., Asgedom, H., Bayissa, B., Ayelet, G., Oura, C.A., Roger, F., 2015. Evaluation of the safety, immunogenicity and efficacy of three capripoxvirus vaccine strains against lumpy skin disease virus. Vaccine 33, 3256-3261.

14. Molla, W., de Jong, M.C., Gari, G., Frankena, K., 2017. Economic impact of lumpy skin disease and cost effectiveness of vaccination for the control of outbreaks in Ethiopia. Preventive veterinary medicine 147, 100-107.

15. Pestova, Y., Byadovskaya, O., Kononov, A., Sprygin, A., 2018. A real time high-resolution melting PCR assay for detection and differentiation among sheep pox virus, goat pox virus, field and vaccine strains of lumpy skin disease virus. Molecular and cellular probes 41, 57-60.

16. Salib, F.A., Osman, A.H., 2011. Incidence of lumpy skin disease among Egyptian cattle in Giza Governorate, Egypt. Vet. World 4(4):162-167

17. Sameea Yousefi, P., Mardani, K., Dalir-Naghadeh, B., Jalilzadeh-Amin, G., 2017. Epidemiological Study of Lumpy Skin Disease Outbreaks in North-western Iran. Transboundary and emerging diseases 64, 1782-1789.

18. Şevik, M., Avci, O., Doğan, M., İnce, Ö.B., 2016. Serum biochemistry of lumpy skin disease virus-infected cattle. BioMed Res. Int., 2016; 2016: 6257984.

19. Tageldin, M.H., Wallace, D.B., Gerdes, G.H., Putterill, J.F., Greyling, R.R., Phosiwa, M.N., Al Busaidy, R.M., Al Ismaaily, S.I., 2014. Lumpy skin disease of cattle: an emerging problem in the Sultanate of Oman. Tropical animal health and production 46, 241-246.

20. Tulman, E., Afonso, C., Lu, Z., Zsak, L., Kutish, G., Rock, D.L., 2001. Genome of lumpy skin disease virus. Journal of virology 75, 7122-7130.

21. Tuppurainen, E.S., Stoltsz, W.H., Troskie, M., Wallace, D.B., Oura, C., Mellor, P.S., Coetzer, J.A., Venter, E.H., 2011. A potential role for ixodid (hard) tick vectors in the transmission of lumpy skin disease virus in cattle. Transboundary and emerging diseases 58, 93-104.

22. Tuppurainen ESM and Oura CAL. 2012.Review: lumpy skin disease: an emerging threat to Europe, the Middle East and Asia. Transbound.emerg. Dis. 59: 40-48. 